\title{
Assessing the Long-term Patency and Clinical Outcomes of Venous and Arterial Grafts Used in Coronary Artery Bypass Grafting: A Meta-analysis
}

Abdul Waheed ${ }^{1}$, Emily Klosterman ${ }^{1}$, Joseph Lee ${ }^{2}$, Ankita Mishra ${ }^{3}$, Vijay Narasimha ${ }^{4}$, Faiz Tuma ${ }^{5}$, Faran Bokhari ${ }^{6}$, Furqan Haq ${ }^{7}$, Subhasis Misra ${ }^{1}$

1. Surgery, Brandon Regional Hospital, Brandon, USA 2. General Surgery, East Tennessee State University, Johnson City, USA 3. Surgery, HCA West Florida Consortium / Brandon Regional Hospital - USF Affiliate, Brandon, USA 4. Surgery/vascular, Brandon Regional Hospital/hca-Usf Consortium, Brandon, USA 5. General Surgery, Central Michigan University College of Medicine, Saginaw, USA 6. Surgery, John H. Stroger, Jr. Hospital of Cook County, Chicago, USA 7. Internal Medicine, Oak Hill Hospital, Tampa, USA

Corresponding author: Subhasis Misra, subhasis.misra@hcahealthcare.com

\section{Abstract \\ Introduction}

The long-term patency of the grafts used during the coronary artery bypass grafting $(\mathrm{CABG})$ is one of the most significant predictors of the clinical outcomes. The gold standard graft used during CABG with the best long-term patency rate and the better clinical outcomes is left internal thoracic artery (LITA) grafted to the left coronary artery (LCA). The controversy lies in choosing the second-best conduit for the non-left coronary artery (NLCA) with similar patency rate as LITA. This meta-analysis examines the long-term patency and clinical outcomes of all arterial grafts versus all venous grafts used during the CABG.

\section{Methods}

A comprehensive literature search of all published randomized control trials (RCTs) assessing long-term patency and clinical outcomes of grafts used in CABG was conducted using PubMed, Cochrane Central Registry of Controlled Trials, and Google Scholar (1966-2018). Keywords searched included combinations of "CABG", "venous grafts in CABG", "arterial grafts in CABG", "radial artery grafts in CABG", "gastroepiploic artery grafts in CABG", "patency and clinical outcomes". Inclusion criteria included: RCTs comparing the long-term patency, and clinical outcomes of radial artery, right internal thoracic artery, gastroduodenal artery, and saphenous vein grafts used in CABG. Long-term patency of the grafts and clinical outcomes were analyzed.

\section{Results}

Eight RCTs involving 2,091 patients with 1,164 patients receiving arterial grafts and 927 patients receiving venous grafts were included. There was no difference between the long-term patency rate (relative risk (RR)

Received 08/06/2019

Review began 09/07/2019 Review ended 09/07/2019 Published 09/16/2019

\section{(c) Copyright 2019}

Waheed et al. This is an open access article distributed under the terms of the Creative Commons Attribution License CC-BY 3.0., which permits unrestricted use, distribution, and reproduction in any medium, provided the original author and source are credited.
$=1.050,95 \%$ confidence interval $(\mathrm{CI})=0.949$ to 1.162 , and $\mathrm{p}=0.344)$, overall mortality rate $(\mathrm{RR}=1.095,95 \%$ $\mathrm{CI}=0.561$ to 2.136 , and $\mathrm{p}=0.790)$, rate of myocardial infarction $(\mathrm{MI})(\mathrm{RR}=0.860,95 \% \mathrm{CI}=0.409$ to 1.812 , and $\mathrm{P}=0.692)$, and re-intervention rate $(\mathrm{RR}=0.0768,95 \% \mathrm{CI}=0.419$ to 1.406 , and $\mathrm{P}=0.392)$ between arterial and venous grafts.

\section{Conclusion}

The use of arterial conduits over the venous conduits has no significant superiority regarding the long-term graft patency, the rate of MI, overall mortality, and the rate of revascularization following CABG. Additional adequately powered studies are needed to further evaluate the long-term outcomes of arterial and venous grafts following the CABG.

Categories: Cardiac/Thoracic/Vascular Surgery, Cardiology, General Surgery

Keywords: coronary artery bypass graft (cabg), arterial grafts, venous grafts, long term outcomes, patency, mortality

\section{Introduction}

Coronary artery bypass grafting $(\mathrm{CABG})$ is the most efficient treatment for symptomatic multivessel coronary artery disease [1]. Every year, more than 800,000 patients undergo CABG worldwide [2]. The most effective approach used during the CABG is the anastomosis of the left internal thoracic (mammary) artery to the left anterior descending artery [1-3]. The 10-year patency rate of the left internal thoracic artery graft is $90 \%[4,5]$. The long-term outcomes following CABG depend mostly on the patency of the vessels grafted to the coronary arteries $[4,6]$. Over the years, a range of arterial and venous grafts have been used during CABG to achieve maximum myocardial perfusion [2]. The great saphenous vein (GSV) is often used as an aortocoronary conduit for the non-left anterior descending (LAD) coronary artery $[7,8]$. Due to the larger 
caliber of the great saphenous vein compared to the target coronary artery, graft closure is always a possible complication. Also, the late closure is due to vein graft atherosclerosis, which results in a $50 \%$ to $60 \%$ closure rate at 10 years [8].

Recently, radial artery (RA) grafts have been revived by several studies which demonstrated excellent longterm patency $[8,9]$. Many authors support the use of radial artery grafts due to the biological properties, adaptation to blood flow, and minimal intimal proliferation, which all lead to improved efficacy compared with saphenous vein grafts $[6,10,11]$. While several clinical studies support the routine use of radial artery instead of saphenous vein conduits, others suggest the opposite [8]. Controversy over the long-term patency and clinical outcomes with the use of arterial and venous grafts for non-LAD coronary arteries exists. This meta-analysis updates the previous meta-analysis (2013) by including three additional randomized control trials (RCTs) in an attempt to more precisely explain the long-term patency and clinical outcomes of all arterial and venous grafts used during CABG [8].

\section{Materials And Methods}

\section{Study selection}

A comprehensive search of all published RCTs comparing long-term patients and clinical outcomes of the radial artery, gastroduodenal artery, and saphenous vein was conducted using PubMed, Google Scholar, and Cochrane Central Registry of Controlled Trials (1966-2018). Additional citations were searched using references retrieved from prior publications (Figure 1). The last search was conducted on November 10, 2018, and only articles conducted in English were considered. Keywords searched included combinations of 'CABG,' 'venous grafts in CABG,' 'arterial grafts in CABG,' and 'patency and clinical outcomes.' The inclusion criteria were limited to RCTs comparing the long-term patency, and clinical outcomes of the patients receiving arterial grafts (radial artery, right gastroepiploic artery, right internal thoracic artery, left internal thoracic artery) and saphenous vein grafts during CABG. In the case of duplicate publications, only the most recent and updated report of the clinical trial was included.

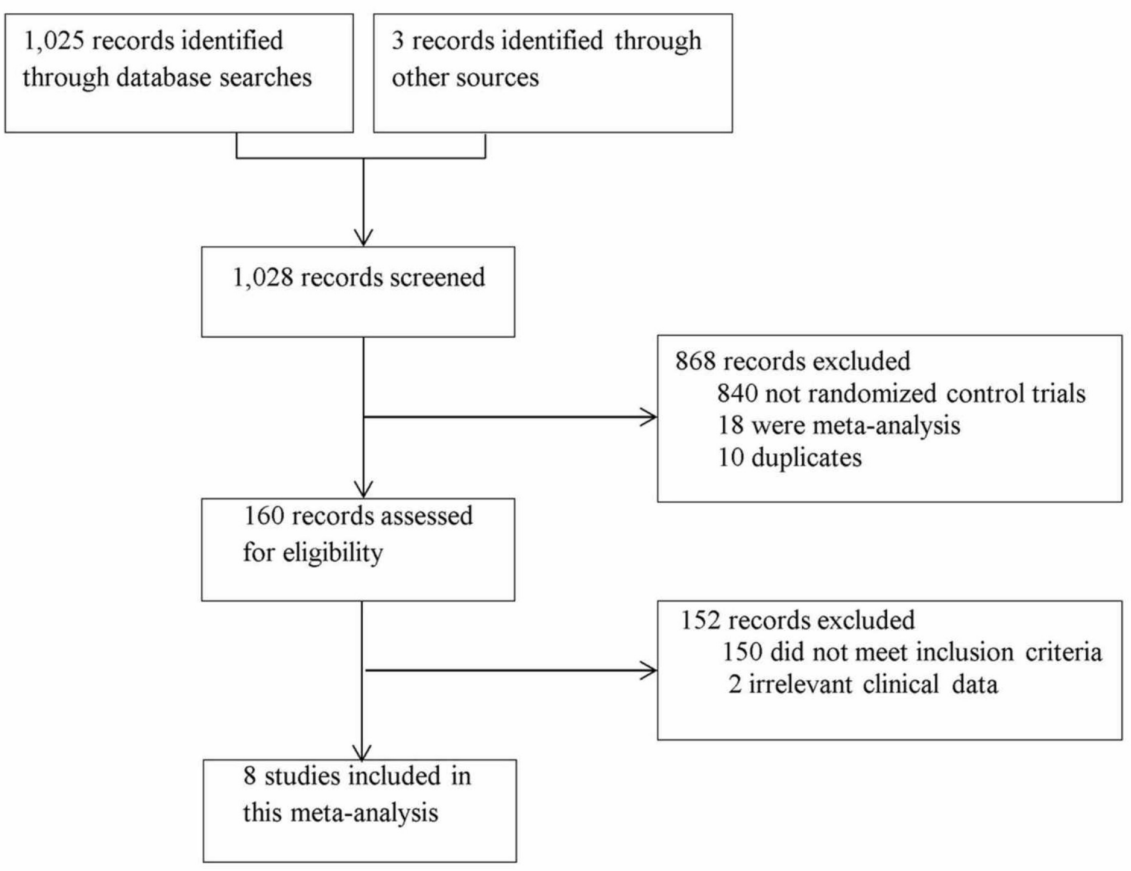

FIGURE 1: CONSORT diagram of the study selection

CONSORT: Consolidated Standards of Reporting Trials

\section{Data extraction}

Articles retrieved from this search were assessed for eligibility and data pertaining to patients, intervention, comparison groups, outcomes, and methodology were abstracted. The primary clinical outcome of interest was long-term patency. Secondary outcomes included were myocardial infarction, overall mortality, and revascularization (Table 1 ). 


\section{Cureus}

\begin{tabular}{|c|c|c|c|c|c|c|c|}
\hline $\begin{array}{l}\text { (Author, } \\
\text { Year) } \\
\text { PMID\# }\end{array}$ & Country & $\begin{array}{l}\text { Main inclusion/exclusion criteria (ex: age of } \\
\text { patients) }\end{array}$ & $\begin{array}{l}\text { (\#receiving } \\
\text { arterial/\# receiving } \\
\text { venous) }\end{array}$ & $\begin{array}{l}\text { Details } \\
\text { pertaining to } \\
\text { grafts (arterial } \\
\text { and venous } \\
\text { grafts) }\end{array}$ & $\begin{array}{l}\text { Follow- } \\
\text { up } \\
\text { time }\end{array}$ & $\begin{array}{l}\text { On- } \\
\text { pump } \\
\text { vs. } \\
\text { off- } \\
\text { pump }\end{array}$ & $\begin{array}{l}\text { Outcomes } \\
\text { analyzed }\end{array}$ \\
\hline $\begin{array}{l}\text { et al., } \\
2015 \text { [3] } \\
\text { PMID. } \\
26466996\end{array}$ & Serbia & $\begin{array}{l}\text { Inclusion criteria: One target vessel disease for } \\
\text { RA/SVG graft, had at least } 80 \% \text { stenosis, was at } \\
\text { least } 1.5 \mathrm{~mm} \text { in diameter, had no diffuse distal } \\
\text { disease. Exclusion criteria: Positive Allen's test, } \\
\text { history of Raynaud's syndrome or vasculitis, } \\
\text { single-vessel disease, }<80 \% \text { stenosis, patient } \\
\text { undergone any concomitant acquired or } \\
\text { congenital cardiac or aortic surgery. }\end{array}$ & $\begin{array}{l}\text { Total patients = 200; } \\
\text { patients with RA graft = } \\
100 \text {, patients with SV graft } \\
=100\end{array}$ & $\begin{array}{l}\text { placed either on } \\
\text { first ( } 50 \% \text { ) or on } \\
\text { second (15\%) } \\
\text { obtuse marginal } \\
\text { branch. RA } \\
\text { grafts were } \\
\text { never placed to } \\
\text { the right } \\
\text { coronary artery } \\
\text { or diagonal } \\
\text { branch if they } \\
\text { were previously } \\
\text { occluded. }\end{array}$ & 8 years & $\begin{array}{l}100 \% \\
\text { on- } \\
\text { pump }\end{array}$ & $\begin{array}{l}\text { Late graft } \\
\text { patency: RA } \\
=92 \%, \text { SVG = } \\
86 \% \text {; Mortality: } \\
\text { RA = } 12 \text { patients, } \\
\text { SVG = } 12 \\
\text { patients; } \\
\text { Myocardial } \\
\text { infarction: RA = } 7 \\
\text { patients, SVG = } 7 \\
\text { patients; Repeat } \\
\text { myocardial } \\
\text { revascularization: } \\
\text { RA = } 10 \text { patients, } \\
\text { SVG = } 16 \\
\text { patients }\end{array}$ \\
\hline $\begin{array}{l}\text { Zhu et } \\
\text { al., } 2014 \\
\text { [5] PMID. } \\
\text { 23671205 }\end{array}$ & Australia & $\begin{array}{l}\text { Inclusion criteria: This study included all } \\
\text { patients who had undergone at least one } \\
\text { elective, protocol- or symptom-directed } \\
\text { angiogram or CTA and at least one } \\
\text { postoperative lipid assay. Exclusion criteria: } \\
\text { Patients with no pre-operative lipid profile. }\end{array}$ & $\begin{array}{l}\text { Total patients }=413, \mathrm{SV} \\
\text { grafts }=311, \text { LITA grafts }= \\
408, \text { RA grafts }=226, \text { RITA } \\
\text { grafts }=137\end{array}$ & & $\begin{array}{l}9.4 \\
\text { years }\end{array}$ & $\begin{array}{l}100 \% \\
\text { on- } \\
\text { pump }\end{array}$ & $\begin{array}{l}\text { Graft failure: SV } \\
\text { graft failure }=88 \\
(20 \%) . \text { All arterial } \\
\text { graft failure rate } \\
=66(8.6 \%)\end{array}$ \\
\hline $\begin{array}{l}\text { Gaudino } \\
\text { et al., } \\
2005 \text { [9] } \\
\text { PMID. } \\
16159829\end{array}$ & Italy & $\begin{array}{l}\text { Inclusion criteria: Primary elective isolated } \\
\text { CABG, previous percutaneous coronary } \\
\text { angioplasty with successful stent implantation } \\
\text { in any coronary vessel } 1.2 \mathrm{~mm} \text { in diameter at } \\
\text { least one month before surgery } \\
\text { with preoperative angiographic demonstration } \\
\text { of patency ( } \mathrm{N}=60 \text {, control group), } \\
\text { intracoronary stent, angiographic evidence of } \\
\text { triple-vessel coronary artery disease with a } \\
\text { disease (i.e., proximal stenosis } 70 \% \text { ) graftable } \\
\text { (i.e.,1 mm in diameter) obtuse marginal artery } \\
\text { (OM) type I according to the classification } \\
\text { proposed by McAlpine, good preoperative left } \\
\text { ventricular function (ejection fraction } 0.50 \text { ) and } \\
\text { no preoperative evidence or history of lateral or } \\
\text { posterolateral myocardial infarction. Exclusion } \\
\text { criteria: Patients who underwent stent } \\
\text { implantation one month before surgery. }\end{array}$ & $\begin{array}{l}\text { Total patients = 120, RA } \\
\text { grafts = 40, SV grafts = } 40 \text {, } \\
\text { RIMA grafts = 40; Total } \\
\text { patients followed by } \\
\text { angiography = 120, RA } \\
\text { grafts followed by } \\
\text { angiography = 40, SV } \\
\text { grafts followed by } \\
\text { angiography = 40, RIMA } \\
\text { grafts followed by } \\
\text { angiography = } 40\end{array}$ & $\begin{array}{l}\text { RA, SV, and } \\
\text { RIMA were } \\
\text { grafted to the } \\
\text { circumflex } \\
\text { coronary artery. }\end{array}$ & $\begin{array}{l}5.4 \\
\text { years }\end{array}$ & $\begin{array}{l}100 \% \\
\text { on- } \\
\text { pump }\end{array}$ & $\begin{array}{l}\text { Late graft } \\
\text { patency artery = } \\
73 / 80, \text { Veins = } \\
25 / 40\end{array}$ \\
\hline $\begin{array}{l}\text { Dreifaldt } \\
\text { et } \\
\text { al., } 2013 \\
\text { [12] } \\
\text { PMID. } \\
23684156\end{array}$ & Sweden & $\begin{array}{l}\text { Inclusion criteria: Patients who had at least } \\
\text { three-vessel coronary artery disease. Exclusion } \\
\text { criteria: Age > } 65 \text { years, left ventricular ejection } \\
\text { fraction } 120 \mathrm{mmol} / \mathrm{L} \text {, use of anticoagulants, } \\
\text { coagulopathy, allergy to contrast medium, } \\
\text { positive Allen's test result or an abnormal result } \\
\text { of Doppler study of the arms, a history of } \\
\text { vasculitis or Raynaud's syndrome, bilateral } \\
\text { varicose veins, or previous vein stripping. }\end{array}$ & $\begin{array}{l}\text { Total patients in the study } \\
=108 \text {; Total patients with } \\
\text { angiographic follow-up = } \\
\text { 99; RA grafts = 108; SV } \\
\text { grafts = } 108\end{array}$ & $\begin{array}{l}\text { Each patient } \\
\text { received one } \\
\text { LITA, one RA, } \\
\text { and one No } \\
\text { Touch (NT) SV } \\
\text { graft as conduit } \\
\text { material. The } \\
\text { LITA was used } \\
\text { to bypass the } \\
\text { left anterior } \\
\text { descending } \\
\text { coronary artery, } \\
\text { and the RA and } \\
\text { NT SV grafts } \\
\text { were } \\
\text { randomized to } \\
\text { bypass either }\end{array}$ & 3 year & $\begin{array}{l}100 \% \\
\text { on- } \\
\text { pump }\end{array}$ & $\begin{array}{l}\text { Graft patency: } \\
\text { RA graft patency } \\
=81 \text { patients, SV } \\
\text { graft patency = } \\
93 \text { patients. } \\
\text { Cardiac death: } \\
\text { RA = - ; SV = - } \\
\text {. Myocardial } \\
\text { infarction: RA = - } \\
\text {; SV = - . Repeat } \\
\text { coronary } \\
\text { intervention: RA } \\
=- \text {; SV = - . }\end{array}$ \\
\hline
\end{tabular}




\section{Cureus}

\begin{tabular}{|c|c|c|c|c|c|c|c|}
\hline \multirow[b]{2}{*}{$\begin{array}{l}\text { Deb et } \\
\text { al., } 2012 \\
\text { [13] } \\
\text { PMID. } \\
\text { 22742399 }\end{array}$} & \multirow[b]{2}{*}{ Canada } & \multirow[b]{2}{*}{$\begin{array}{l}\text { Inclusion criteria: Age }<80 \text { years, three-vessel } \\
\text { disease, non-LAD. Exclusion criteria: Positive } \\
\text { Allen's test, Vasculitis or Raynaud's syndrome, } \\
\text { bilateral varicose veins. }\end{array}$} & & \multicolumn{4}{|l|}{$\begin{array}{l}\text { the left or the } \\
\text { right coronary } \\
\text { territory. }\end{array}$} \\
\hline & & & $\begin{array}{l}\text { Total patients in the study } \\
=510 ; \text { RA graft = } 510 ; \text { SV } \\
\text { graft = 510; Number of } \\
\text { patients with angiographic } \\
\text { follow-up = 269; RA grafts } \\
\text { in follow-up patients = } \\
269 ; \text { SV grafts in follow-up } \\
\text { patients = } 269\end{array}$ & $\begin{array}{l}\text { RA grafted to } \\
\text { the right } \\
\text { coronary artery } \\
\text { or left circumflex } \\
\text { artery. SV } \\
\text { grafted to the } \\
\text { opposite } \\
\text { territory. }\end{array}$ & $\begin{array}{l}7.7 \\
\text { years }\end{array}$ & - & $\begin{array}{l}\text { Graft failure: RA } \\
=28 / 269 ; \text { SV = } \\
\text { 50/269. Cardiac } \\
\text { death: RA = } \\
0 / 510 ; \text { SV = } \\
1 / 510 . \\
\text { Myocardial } \\
\text { infarction: RA = } \\
\text { 2/510; SV = } \\
\text { 3/510. Repeat } \\
\text { coronary } \\
\text { intervention: RA } \\
=3 / 510 ; \text { SV = } \\
\text { 12/510 }\end{array}$ \\
\hline $\begin{array}{l}\text { Deb et } \\
\text { al., } 2014 \\
\text { [14] } \\
\text { PMID. } \\
25109754\end{array}$ & Canada & $\begin{array}{l}\text { Inclusion criteria: Age < } 80 \text { years, patients with } \\
\text { triple-vessel disease. Exclusion criteria: } \\
\text { Contraindication for the use of the RA (i.e., } \\
\text { positive Allen's test), abnormal arterial upper } \\
\text { limb duplex scan, a history of vasculitis } \\
\text { (Raynaud's syndrome) or the SV (i.e., bilateral } \\
\text { varicosities or vein stripping). Further exclusion } \\
\text { criteria were factors limiting follow-up research } \\
\text { angiography, which included creatinine greater } \\
\text { than } 180 \text { mmol/L, severe peripheral vascular } \\
\text { disease limiting femoral access, coagulopathy } \\
\text { or obligatory use of anticoagulants, known } \\
\text { allergy to radiographic contrast, pregnancy, and } \\
\text { geographic inaccessibility. }\end{array}$ & $\begin{array}{l}\text { Total patients = 529; } \\
\text { patients for long-term } \\
\text { angiographic follow-up = } \\
\text { 269; Total DM patients = } \\
\text { 148; Total DM patients for } \\
\text { long-term angiographic } \\
\text { follow-up = 83; Total non- } \\
\text { DM patients with long- } \\
\text { term angiographic follow- } \\
\text { up = 186; Total DM } \\
\text { patients receiving RA } \\
\text { grafts = 83; Total non-DM } \\
\text { patients receiving RA } \\
\text { grafts = 186; Total DM } \\
\text { patients receiving SV } \\
\text { grafts = 83; Total non-DM } \\
\text { patients receiving SV } \\
\text { grafts = 186 }\end{array}$ & $\begin{array}{l}\text { The RA was } \\
\text { randomized to } \\
\text { the inferior (right } \\
\text { coronary artery) } \\
\text { or lateral } \\
\text { (circumflex } \\
\text { artery) region of } \\
\text { the heart. The } \\
\text { SV graft was } \\
\text { placed at the } \\
\text { opposing } \\
\text { territory } \\
\text { (circumflex } \\
\text { artery or right } \\
\text { coronary } \\
\text { artery). }\end{array}$ & $\begin{array}{l}\text { After } 5 \\
\text { years }\end{array}$ & $\begin{array}{l}100 \% \\
\text { on- } \\
\text { pump }\end{array}$ & $\begin{array}{l}\text { Late graft } \\
\text { patency: DM and } \\
\text { RA graft = } \\
91.5 \% \text {; DM and } \\
\text { SV graft = 79.7\%; } \\
\text { Non-DM with RA } \\
\text { graft = 90.3\%; } \\
\text { Non-DM with SV } \\
\text { graft = 86.2\%. } \\
\text { Complete graft } \\
\text { occlusion: DM } \\
\text { and RA graft = } \\
4.8 \% ; \text { DM and SV } \\
\text { graft = 25.3\%; } \\
\text { Non-DM with RA } \\
\text { graft = } 10.8 \% ; \\
\text { Non-DM with SV } \\
\text { graft = } 15.6 \%\end{array}$ \\
\hline $\begin{array}{l}\text { Hayward } \\
\text { et } \\
\text { al., Group } \\
1,2011 \\
\text { [15] } \\
\text { PMID. } \\
21392707\end{array}$ & Australia & $\begin{array}{l}\text { Inclusion criteria: Age > } 70 \text { years, three-vessel } \\
\text { disease, non-LAD. Exclusion criteria: Positive } \\
\text { Allen's test, vasculitis or Raynaud's syndrome, } \\
\text { bilateral varicose veins. }\end{array}$ & $\begin{array}{l}\text { Total patients in study = } \\
365 . \text { Total patients for } \\
\text { angiographic follow-up = } \\
227, \text { RA grafts }=186, \text { SV } \\
\text { grafts }=0 \text {, RIMA grafts = } \\
179, \text { RA drafts for follow- } \\
\text { up }=122 \text {, RIMA drafts for } \\
\text { follow-up }=105\end{array}$ & $\begin{array}{l}\text { The largest non- } \\
\text { LAD target was } \\
\text { randomized to } \\
\text { receive either RA } \\
\text { or RIMA. }\end{array}$ & $\begin{array}{l}5.5 \\
\text { years }\end{array}$ & $\begin{array}{l}100 \% \\
\text { on- } \\
\text { pump }\end{array}$ & $\begin{array}{l}\text { Graft failure: RA } \\
=13 / 122, \text { RIMA }= \\
12 / 105\end{array}$ \\
\hline $\begin{array}{l}\text { Hayward } \\
\text { et al., } \\
\text { Group 2, } \\
2011 \text { [15] } \\
\text { PMID. } \\
21392707\end{array}$ & Australia & $\begin{array}{l}\text { Inclusion criteria: Age > } 70 \text { years, three-vessel } \\
\text { disease, Non-LAD. Exclusion criteria: Positive } \\
\text { Allen's test, Vasculitis or Raynaud's syndrome, } \\
\text { bilateral varicose veins. }\end{array}$ & $\begin{array}{l}\text { Total patients in study = } \\
214, \text { total patients for } \\
\text { angiographic follow-up = } \\
110, \text { RA grafts }=104, \text { SV } \\
\text { grafts = 110, RIMA grafts = } \\
0, \text { RA drafts for follow-up = } \\
51, \text { SV drafts for follow-up } \\
=59\end{array}$ & $\begin{array}{l}\text { The largest non- } \\
\text { LAD target was } \\
\text { randomized to } \\
\text { receive either RA } \\
\text { or SV graft. }\end{array}$ & $\begin{array}{l}5.5 \\
\text { years }\end{array}$ & $\begin{array}{l}100 \% \\
\text { on- } \\
\text { pump }\end{array}$ & $\begin{array}{l}\text { Graft failure: RA } \\
=4 / 51, \mathrm{SV}= \\
\text { 9/59. Cardiac } \\
\text { death: RA = } \\
4 / 113, \mathrm{SV}= \\
2 / 112 . \\
\text { Myocardial } \\
\text { infarction: RA = } \\
\text { 4/113, SV = } \\
\text { 4/112, Repeat } \\
\text { coronary } \\
\text { intervention: RA } \\
=1 / 113, \mathrm{SV}= \\
4 / 112\end{array}$ \\
\hline $\begin{array}{l}\text { Collins et } \\
\text { al., } 2008 \\
{[16]}\end{array}$ & UK & $\begin{array}{l}\text { Inclusion criteria: Age } 40-70 \text { years, two-vessel } \\
\text { disease, and left circumflex coronary artery } \\
\text { stenosis. Exclusion criteria: LV ejection fraction }\end{array}$ & $\begin{array}{l}\text { Total patients in the study } \\
=142, \text { patients with RA } \\
\text { graft }=82, \text { with SV graft = } \\
60 . \text { Patients with } \\
\text { angiographic follow-up = } \\
103, \text { RA grafts for }\end{array}$ & $\begin{array}{l}\text { RA or SV grafted } \\
\text { to left circumflex }\end{array}$ & 5 years & $\begin{array}{l}100 \% \\
\text { on- }\end{array}$ & $\begin{array}{l}\text { Graft patency: } \\
R A=98.3 \%, \text { SV }\end{array}$ \\
\hline
\end{tabular}




\section{Cureus}

PMID.

18506009
$<25 \%$, positive Allen's test, a history of Raynaud's syndrome, bilateral varicose veins. angiographic follow-up =

coronary artery

pump $=86.4 \%$
59 , SV grafts for

angiographic follow-up =

\section{TABLE 1: Characteristics of included studies}

PMID: PubMed IDentifier; RA: Radial artery; SVG: Saphenous vein graft; SV: Saphenous vein; DM: Diabetes mellitus; LITA: Left internal thoracic artery; RITA: Right internal thoracic artery; LAD: Left anterior descending; CABG: Coronary artery bypass grafting.

\section{Statistical analysis}

For each trial, relative risk (RR) with a 95\% confidence interval (CI) for long-term patency, overall mortality, myocardial infarction, and revascularization were calculated. The standard difference in mean (SDM) with 95\% CI were calculated for patency rate, myocardial infarction graft failure, and revascularization. A metaanalysis of the pooled data was performed using the Comparative Meta-Analysis software Version 3 (Biostat, Englewood, NJ). For individual studies reporting zero events in any group, a continuity correction factor of 0.5 was adopted to calculate the RR and variance. Both the fixed effects model and the random-effects model were considered, depending on the heterogeneity of the included studies. To assess the heterogeneity between studies, both Cochrane's Q statistic and I2 statistic were used. Heterogeneity was considered statistically significant when $\mathrm{p}<0.05$ or I $>50$. If heterogeneity was observed, data were analyzed using a random-effects model. In the absence of heterogeneity, a fixed-effects model was assumed.

For all the outcomes, publication bias was first evaluated using a funnel plot and further evaluated with Egger's and Begg's tests. A two-tailed p-value of $<0.05$ was considered statistically significant.

\section{Results}

\section{Demographic characteristics of the studies}

A total of eight RCTs were identified, involved 2,091 patients, of which 1,164 patients received arterial grafts and 927 patients received venous grafts. The primary outcome was long-term graft patency. Mortality, reintervention, and rate of myocardial infarction were identified as secondary outcomes from these studies (Table 1).

\section{Assessment of the long-term graft patency}

All eight trials reported on the long-term patency of the arterial and venous grafts. No significant heterogeneity was noticed amongst the trials. Analysis resulted in no significant difference in long-term patency between the two groups $(\mathrm{RR}=1.050,95 \% \mathrm{CI}=0.949$ to 1.162 , and $\mathrm{p}=0.344$ ) (Figure 2) (Table 1).

\begin{tabular}{|c|c|c|c|c|c|c|c|c|c|}
\hline \multirow[t]{2}{*}{ Study name } & \multirow[b]{2}{*}{$\begin{array}{l}\text { Risk } \\
\text { ratio }\end{array}$} & \multicolumn{3}{|c|}{ Statistics for each study } & \multirow[b]{2}{*}{ p-Value } & & \multicolumn{2}{|c|}{ Fisk ratio and $95 \%$ a } & \\
\hline & & $\begin{array}{l}\text { Lower } \\
\text { limit }\end{array}$ & $\begin{array}{l}\text { Upper } \\
\text { limit }\end{array}$ & Z-Value & & & & & \\
\hline Petrovic et al.2015 & 1.043 & 0.857 & 1.271 & 0.424 & 0.672 & & & d & \\
\hline Deb S et al.2014 & 1.119 & 1.045 & 1.198 & 3.221 & 0.001 & & & & \\
\hline Zhu YYet al.2014 & 1.149 & 1.064 & 1.242 & 3.520 & 0.000 & & & & \\
\hline Dreifaldt et al.2013 & 0.871 & 0.784 & 0.968 & -2.567 & 0.010 & & & & \\
\hline Hayward et al.2011 & 1.057 & 0.942 & 1.186 & 0.940 & 0.347 & & & & \\
\hline Glineur et al. 2011 & 0.783 & 0.672 & 0.911 & -3.158 & 0.002 & & & & \\
\hline Collins et al., 2008 & 1.138 & 1.007 & 1.286 & 2.079 & 0.038 & & & & \\
\hline \multirow{4}{*}{ Study group. 2005} & 1.460 & 1.138 & 1.874 & 2.973 & 0.003 & & & & \\
\hline & 1.050 & 0.949 & 1.162 & 0.945 & 0.344 & & & & \\
\hline & & & & & & 0.01 & 0.1 & 10 & 100 \\
\hline & & & & & & & Favours Atterial & Favours Venous & \\
\hline
\end{tabular}

\section{Meta Analysis}

FIGURE 2: Forest plot: The long-term patency of arterial and venous conduits

Petrovic et al., 2015 [3]

Deb et al., 2014 [14]

Zhu et al., 2014 [5] 


\section{Cureus}

Dreifaldt et al., 2013 [12]

Hayward et al., 2011 [15]

Collins et al., $2008[16]$

\section{Assessment of the overall mortality}

Two studies provided the data on overall mortality $[3,12]$. No significant heterogeneity was noticed between the trials. The analysis resulted in no significant difference in the overall mortality rate between the two groups. The pooled RR was $1.095(95 \% \mathrm{CI}=0.561$ to 2.136 , and $\mathrm{p}=0.790)$ (Figure 3) (Table 1 ).

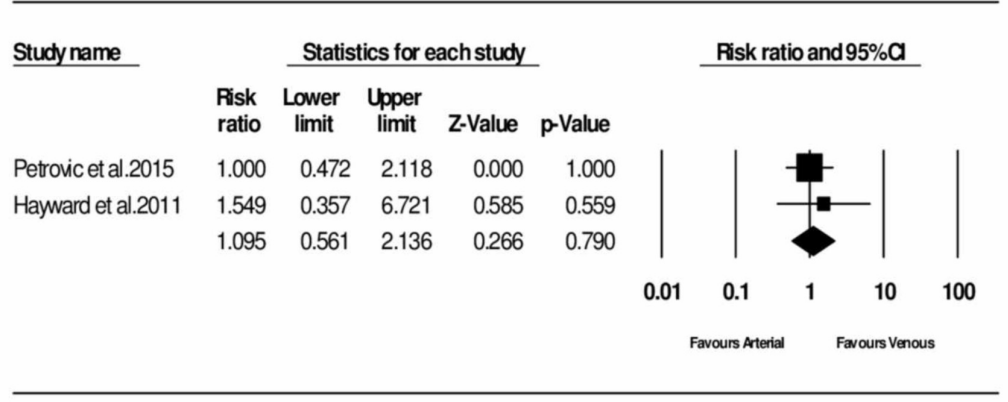

Meta Analysis

FIGURE 3: Forest plot: Overall mortality of arterial and venous conduits

Petrovic et al., 2015 [3]

Hayward and Buxton, 2011 [15]

\section{Assessment of the incidence of myocardial infarction}

Two trials provided the data on overall mortality $[4,8]$. No significant heterogeneity was noticed between the trials. This current meta-analysis reports no significant difference in the rate of myocardial infarction between the two groups. The pooled RR was 0.860 ( $95 \% \mathrm{CI}=0.409$ to 1.812 , and $\mathrm{P}=0.692$ ) (Figure 4 ) (Table 1).

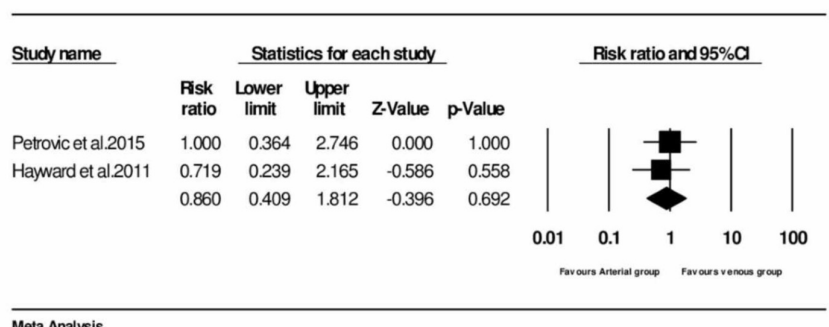

FIGURE 4: Forest plot: Incidence of myocardial infarction between arterial and venous conduits

Petrovic et al., 2015 [3]

Hayward and Buxton, 2011 [15]

\section{Assessment of the re-intervention rate}

Two trials provided the data on the re-intervention rate $[3,12]$. No significant heterogeneity was noticed between the trials. The analysis resulted in no significant difference in the re-intervention rate between the 


\section{Cureus}

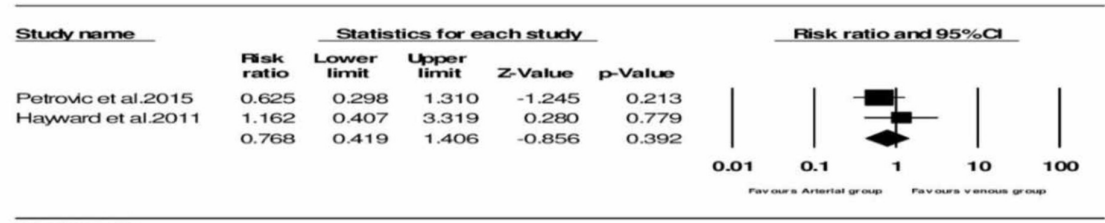

Meta Analysis

FIGURE 5: Forest plot: Re-intervention rate between arterial and venous conduits

Petrovic et al., 2015 [3]

Hayward and Buxton, 2011 [15]

\section{Publication bias}

A funnel plot was used to assess for publication bias visually, and both Egger's and Begg's tests were performed to calculate publication bias. There was no obvious evidence of asymmetry on the funnel plot (Figure 6). Furthermore, there was no evidence of the publication bias for the primary endpoint of this study (long-term patency of arterial and venous grafts in CABG) by either the Egger's $(p=0.671)$ or Beggs's test ( $p$ $=0.901)$.

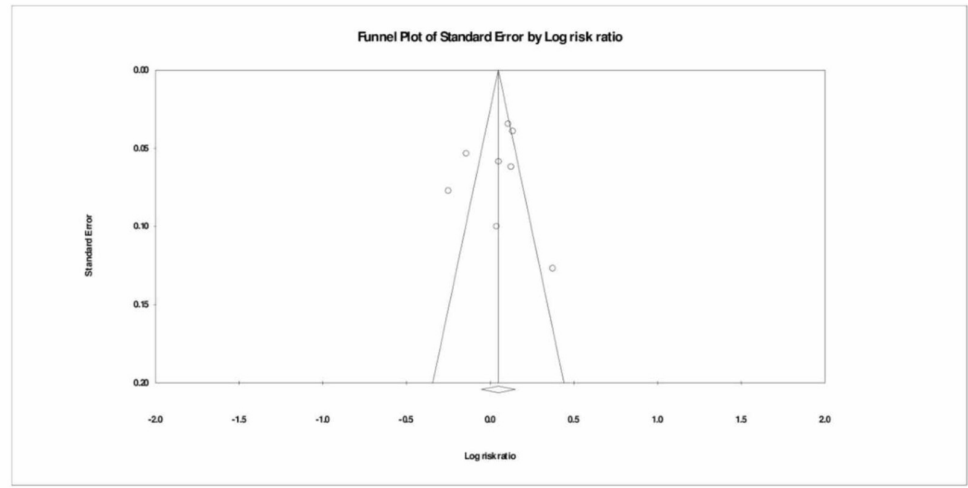

FIGURE 6: Funnel plot assessing publication bias (analyzing the longterm patency of the arterial and venous grafts)

\section{Discussion}

Coronary-artery bypass grafting (CABG) was first introduced in the 1960s, which became the standard of care for symptomatic patients with coronary artery disease [1]. The long-term patency of the grafts used during CABG is one of the most critical determinants of the excellent clinical outcomes [4, 13]. The choice of conduit used during the CABG with the best long-term outcomes has evolved over the years [17]. In 1964, Kolesov performed the first successful internal mammary artery-coronary artery anastomosis [18, 19]. During the same decade, Favaloro reported using saphenous vein to restore coronary artery blood flow [20].

In 1973, Carpentier et al. used radial artery for the first time as a conduit for the CABG, but this idea did not 
gain popularity due to the early rejection of the graft [21, 22]. The idea of using radial artery as an effective graft reemerged in 1990 when early graft rejection of radial artery was prevented with the use of calcium channel blockers [13, 22-24].

The patency of grafts has primarily assessed the success rate of coronary artery bypass grafting [14, 25]. Unfortunately, there is no clear evidence for selecting best second graft with comparable long-term patency to LITA-to-LAD graft. Several RCTs have reported discordant results on the long-term patency superiority of a second arterial or venous conduit $[4,15]$. This study compares the long-term patency of all the arterial and venous grafts and associated long-term clinical outcomes.

The patency of vessels grafted to the coronary arteries has been divided into three stages: early patency $(<6$ months), medium-term patency (6-36 months), long-term patency (>36 months) [8]. Several factors contribute to the patency of a grafted vessel, and one of them is the biological properties of the vessel wall $[2,8]$. There is a general agreement that long-term patency of arteries and veins are dependent on their biological makeup and their resistance to atherosclerosis $[2,8,26]$. The arterial conduits are considered more favorable for the high-pressure arterial environment in the coronary arteries [8]. The shear stress in the arterial environment induces compensatory mechanisms in endothelial cells of the arterial walls that lead to the release of local vasodilators like nitric oxide and prostaglandins and also inhibit the constricting factors like endothelian $[24,27]$. All these biochemical changes enable the arterial wall to be more resistant to the high arterial pressure [8]. However, merely the quality of the evidence above does not lead to the definitive conclusion to support the use only arterial grafts for CABG [8].

There has been marked variability in the reported long-term patency and graft occlusion of arterial and venous grafts. Athanasiou et al. included both randomized trials and observational studies in a metaanalysis to compare the patency rates at follow-up intervals of $>5$ years. They concluded that rate of late graft occlusion was significantly reduced in radial artery group compared to saphenous venous group [for observational and randomized trials, $\mathrm{OR}=0.520$ ( $95 \% \mathrm{CI}$ : 0.34 to $0.79, \mathrm{p}=0.002$ ); for RCTs alone, $\mathrm{OR}=0.49$ (95\% CI $=0.31$ to $0.77, \mathrm{p}=0.002)][2]$.

Another single-center study, Radial Artery Versus Saphenous Vein Patency (RSVP), reported that complete graft occlusion at a follow-up of 5.5 years was markedly less frequent in radial grafts compared to the saphenous vein group [16]. On the other hand, the RCT conducted by Buxton et al., comparing the RA with the free right internal thoracic artery (RITA) and the saphenous vein graft (SVG), did not support the superior patency of the RA compared with the RITA or the SVG [28]. Similar findings were reported in a recent RCT conducted by Petrovic et al. [3]. They enrolled 200 patients and randomly assigned them to the radial artery group (100 patients) and saphenous venous group (100 patients). At a follow-up of eight years, the patency rate was $92 \%$ in the radial artery group and $86 \%$ in the saphenous venous group $(p=0.67)$ [3]. These results are consistent with the findings of this meta-analysis.

For the secondary outcomes, this meta-analysis suggests that the overall mortality rate, revascularization, and rate of myocardial infarction are not significantly different in either arterial or venous groups. In the Stand-in-Y trial, the survival rate was similar in patients who received a radial artery compared with a second ITA graft. These results are also consistent with the findings of this meta-analysis. They enrolled 3,102 patients; 1,554 were randomly assigned to receive single internal-thoracic-artery grafts, and 1,548 received bilateral internal-thoracic-artery grafts. At five years of follow-up, the mortality rate was $8.7 \%$ in those patients who received bilateral-grafts and $8.4 \%$ in those who received single artery grafts (Hazard ratio $(\mathrm{HR})=1.04 ; 95 \% \mathrm{CI}=0.81-1.32 ; \mathrm{P}=0.77$ ), and the mortality rate of death from myocardial infarction was $12.2 \%(\mathrm{HR}=0.96 ; 95 \% \mathrm{CI}=0.79-1.17 ; \mathrm{P}=0.69)$. On the other hand, in a single-center observational study, the survival rate was enhanced with the use of the radial artery compared with a saphenous vein [29]. In 2004, Zacharias et al. reported the six-year clinical outcomes of propensity-matched patients undergoing LIMA-LAD, using either RA or SVG for additional graphs as a secondary conduit. In 925 patients, they found cumulative survival was better with the RA grafts [30].

Some of the limitations should be acknowledged about the present study, and the results should be interpreted with caution. First of all, all the studies included in this meta-analysis are small, with the largest having 529 participants. Also, studies do not have a fixed follow-up interval. Other limitations of this study include the power of individual secondary outcomes.

\section{Conclusions}

Despite these limitations, the results from this meta-analysis indicate that the use of arterial conduits over the venous conduits for $C A B G$ has no statistically significant effect regarding long-term graft patency, the rate of MI, overall mortality, and the rate of revascularization following CABG. More massive, multi-center randomized control trials are needed to be done in order to determine long-term patency of arterial and venous grafts. It is recommended that the studies must take into consideration the effects of various drugs the patients are taking and their influence on the long-term patency and clinical outcomes.

\section{Additional Information}




\section{Disclosures}

Human subjects: All authors have confirmed that this study did not involve human participants or tissue. Animal subjects: All authors have confirmed that this study did not involve animal subjects or tissue. Conflicts of interest: In compliance with the ICMJE uniform disclosure form, all authors declare the following: Payment/services info: All authors have declared that no financial support was received from any organization for the submitted work. Financial relationships: All authors have declared that they have no financial relationships at present or within the previous three years with any organizations that might have an interest in the submitted work. Other relationships: All authors have declared that there are no other relationships or activities that could appear to have influenced the submitted work.

\section{References}

1. Serruys PW, Morice MC, Kappetein AP, et al.: Percutaneous coronary intervention versus coronary-artery bypass grafting for severe coronary artery disease. N Engl J Med. 2009, 360:961-972. 10.1056/NEJMoa0804626

2. Athanasiou T, Saso S, Rao C, et al.: Radial artery versus saphenous vein conduits for coronary artery bypass surgery: forty years of competition--which conduit offers better patency? A systematic review and metaanalysis. Eur J Cardiothorac Surg. 2011, 40:208-220. 10.1016/j.ejcts.2010.11.012

3. Petrovic I, Nezic D, Peric M, et al.: Radial artery vs saphenous vein graft used as the second conduit for surgical myocardial revascularization: long-term clinical follow-up. J Cardiothorac Surg. 2015, 10:127.

4. Benedetto U, Raja GS, Albanese A, Amrani M, Biondi-Zoccai G, Frati G: Searching for the second best graft for coronary artery bypass surgery: a network meta-analysis of randomized controlled trials. Eur J Cardiothorac Surg. 2015, 47:59-65. 10.1093/ejcts/ezu111

5. Zhu YY, Hayward ARP, Hare AD, Reid C, Stewart AG, Buxton BF: Effect of lipid exposure on graft patency and clinical outcomes: arteries and veins are different. Eur J Cardiothorac Surg. 2014, 45:323-328. 10.1093/ejcts/ezt261

6. Joannides R, Haefeli EW, Linder L, Richard V, Bakkali EH, Thuillez C, Lüscher TF: Nitric oxide is responsible for flow-dependent dilatation of human peripheral conduit arteries in vivo. Circulation. 1995, 91:1314-1319. 10.1161/01.CIR.91.5.1314

7. Captur G: Memento for René Favaloro. Tex Heart Inst J. 2004, 31:47-60.

8. Zhang H, Wang WZ, Wu BH, Hu XP, Zhou Z, Xu P: Radial artery graft vs. saphenous vein graft for coronary artery bypass surgery: which conduit offers better efficacy?. Herz. 2014, 39:458-465. 10.1007/s00059-0133848-5

9. Gaudino M, Cellini C, Pragliola C, et al.: Arterial versus venous bypass grafts in patients with in-stent restenosis. Circulation. 2005, 112:265-269. 10.1161/CIRCULATIONAHA.104.512905

10. Mekontso-Dessap A, Kirsch M, Guignambert C, Zadigue P, Adnot S, Loisance D, Eddahibi S: Vascular-wall remodeling of 3 human bypass vessels: organ culture and smooth muscle cell properties. J Thorac Cardiovasc Surg. 2006, 131:651-658. 10.1016/j.jtcvs.2005.08.048

11. Ikeda M, Ohashi H, Tsutsumi Y, Hige K, Kawai T, Ohnaka M: Angiographic evaluation of the luminal changes in the radial artery graft in coronary artery bypass surgery: a concern over the long-term patency. Eur J Cardiothorac Surg. 2002, $21: 800-803.10 .1016 /$ S1010-7940(02)00077-5

12. Dreifaldt M, Mannion DJ, Bodin L, Olsson H, Zagozdzon L, Souza D: The no-touch saphenous vein as the preferred second conduit for coronary artery bypass grafting. Ann Thorac Surg. 2013, 96:105-111. 10.1016/j.athoracsur.2013.01.102

13. Deb S, Cohen AE, Singh KS, Une D, Laupacis A, Fremes SE; RAPS Investigators: Radial artery and saphenous vein patency more than 5 years after coronary artery bypass surgery: results from RAPS (Radial Artery Patency Study). J Am Coll Cardiol. 2012, 60:28-35. 10.1016/j.jacc.2012.03.037

14. Deb S, Singh KS, Moussa F, et al.: The long-term impact of diabetes on graft patency after coronary artery bypass grafting surgery: a substudy of the multicenter Radial Artery Patency Study. J Thorac Cardiovasc Surg. 2014, 148:1246-1253. 10.1016/j.jtcvs.2014.06.057

15. Hayward PA, Buxton BF: The radial artery patency and clinical outcomes trial: design, intermediate term results and future direction. Heart Lung Circ. 2011, 20:187-192. 10.1016/j.hlc.2011.01.001

16. Collins P, Webb CM, Chong CF, Moat NE; Radial Artery Versus Saphenous Vein Patency (RSVP) Trial Investigators: Radial artery versus saphenous vein patency randomized trial: five-year angiographic followup. Circulation. 2008, 117:2859-2864. 10.1161/CIRCULATIONAHA.107.736215

17. Diodato M, Chedrawy EG: Coronary artery bypass graft surgery: the past, present, and future of myocardial revascularisation. Surg Res Pract. 2014, 2014:6. 10.1155/2014/726158

18. Yasuura K, Okamoto H, Seki A, Ogawa Y, Hoshino M, Abe T: The effects of the internal mammary arterycoronary artery bypass surgery: with special reference to improvement of the regional wall motion of the left ventricle. (Article in Japanese). Nihon Geka Gakkai Zasshi. 1988, 89:602-607.

19. Olearchyk AS: Vasilii I. Kolesov. A pioneer of coronary revascularization by internal mammary-coronary artery grafting. J Thorac Cardiovasc Surg. 1988, 96:13-18.

20. Favaloro RG: Saphenous vein autograft replacement of severe segmental coronary artery occlusion: operative technique. Ann Thorac Surg. 1968, 5:334-339. 10.1016/S0003-4975(10)66351-5

21. Carpentier A, Guermonprez LG, Deloche A, Frechette C, DuBost C: The aorta-to-coronary radial artery bypass graft: a technique avoiding pathological changes in grafts. Ann Thorac Surg. 1973, 16:111-121. 10.1016/S0003-4975(10)65825-0

22. Cao C, Ang SC, Wolak K, Peeceeyen S, Bannon P, Yan TD: A meta-analysis of randomized controlled trials on mid-term angiographic outcomes for radial artery versus saphenous vein in coronary artery bypass graft surgery. Ann Cardiothorac Surg. 2013, 2:401-407. 10.3978/j.issn.2225-319X.2013.07.03

23. Acar C, Jebara AV, Portoghese M, et al.: Revival of the radial artery for coronary artery bypass grafting . Ann Thorac Surg. 1992, 54:652-660. 10.1016/0003-4975(92)91007-V

24. Webb CM, Moat NE, Chong CF, Collins P: Vascular reactivity and flow characteristics of radial artery and 


\section{Cureus}

long saphenous vein coronary bypass grafts: a 5-year follow-up. Circulation. 2010, 122:861-867.

10.1161/CIRCULATIONAHA.109.887000

25. Glineur D, D'hoore W, Kerchove DV, Noirhomme P, Price J, Hanet C, Khoury GE: Angiographic predictors of 3-year patency of bypass grafts implanted on the right coronary artery system: a prospective randomized comparison of gastroepiploic artery, saphenous vein, and right internal thoracic artery grafts. J Thorac Cardiovasc Surg. 2011, 142:980-988. 10.1016/j.jtcvs.2011.07.017

26. Wagner TH, Sethi G, Holman W, et al.: Costs and quality of life associated with radial artery and saphenous vein cardiac bypass surgery: results from a Veterans Affairs multisite trial. Am J Surg. 2011, 202:532-535. 10.1016/j.amjsurg.2011.06.011

27. Al-Bustami MH, Amrani M, Chester AH, Ilsley CJ, Yacoub MH: In vivo early and mid-term flow-mediated endothelial function of the radial artery used as a coronary bypass graft. J Am Coll Cardiol. 2002, 39:573-577. 10.1016/s0735-1097(01)01791-0

28. Buxton BF, Raman JS, Ruengsakulrach P, et al.: Radial artery patency and clinical outcomes: five-year interim results of a randomized trial. J Thorac Cardiovasc Surg. 2003, 125:1363-1370. 10.1016/S00225223(02)73241-8

29. Tranbaugh RF, Dimitrova KR, Friedmann P, et al.: Radial artery conduits improve long-term survival after coronary artery bypass grafting. Ann Thorac Surg. 2010, 90:1165-1172. 10.1016/j.athoracsur.2010.05.038

30. Zacharias A, Schwann TA, Riordan CJ, Durham SJ, Shah AS, Habib RH: Late results of conventional versus all-arterial revascularization based on internal thoracic and radial artery grafting. Ann Thorac Surg. 2009, 87:19-26. 10.1016/j.athoracsur.2008.09.050 